\title{
Criteria of determination of age of cognac spirits
}

\author{
O. Lukanin, \\ academician of the NAAS, doctor of technical sciences \\ Winemaking primary resources monitoring laboratory \\ O. Sydorenko, \\ Candidate of Technical Sciences \\ Limited Liability Company «Pioner Noviishykh Tekhnolohii»
}

The purpose. To develop criteria of estimation of ripeness of ordinary cognac spirits on the basis of measurements of concentration of basic aromatic components of oak which pass in spirit at seasoning in a barrel for $1-5$ years. Methods. Experimental seasoning of cognac spirits in new barrels made from domestic oak was spent in industrial conditions. The equation of an index of age of cognac spirits is deduced by means of programs of statistical analysis of data. Concentration of aromatic components of an oak in cognac spirits was measured by chromatographic method. Results. The formula on which it is possible to calculate an index of age of cognac or cognac spirit up to $98,68 \%$ is developed. Conclusions. The criterion of estimation of ripeness of ordinary cognac spirits on the basis of measurements of concentration of basic components of oak which pass during seasoning in barrels for $1-5$ years is offered.

Key words: cognac spirits, aromatic components, classification, time of seasoning.

Free Trade Zone Agreement of Ukraine with the EU, which has come into force on January $01^{\text {st }}, 2016$, is aimed at reducing and abolishing of tariffs for goods, as well as bringing the Ukrainian business rules and regulations into compliance with the EU rules and regulations in order to ensure free movement of goods and services and mutual non-discriminatory attitude towards companies within the territory of Ukraine and the EU. Therefore, it is expedient to consider the possibility of the Ukrainian winemaking industry to compete with cognac and brandy producers of the EU countries.

Cognac is a drink that has a status of Geographical Indication (Indication Geographique (IG), which guarantees the place of its origin and ensures strict compliance with production regulations in France. IG Cognac is based on the principles of traditional production methods preserving [15].

The geographical name "Cognac" by origin was registered by a decree of France dated May 015t, 1909 for the first time, then on May $15^{\text {th }}, 1936$.

In order to obtain the Geographical Indication Status IG Cognac must conform to the specifications approved by the French decree "Cahier des charges" dated June 16 $6^{\text {th }}, 2011$ [15].

IG Cognac, its definition, description, labeling rules and protection of geographical indication of alcoholic drinks at the European level were established by the EU Council Regulation No. 110/2008 of January $15^{\text {th }}$, 2008, which in its turn canceled the EU Council Regulation No. 15676/89. According to the Article 15 of this Regulation, the geographical indication "shall be an indication which identifies a spirit drink as originating in the territory of a country, or a region or locality in that territory, where a given quality, reputation or other characteristic of that spirit drink is essentially attributable to its geographical origin" [17].

From our perspective most Ukrainian cognacs are not competitive in the European and world markets by the name of the drink, organoleptic and physico-chemical indicators.

The name "Ukrainian cognacs" and their classification borrowed from Soviet standards are used in Ukraine, which contradicts the principles of the EU Council Regulation No. 491/2009 dated May 25 2009 and No. 1234/2007 dated October 22 $2^{\text {nd }}, 2007$ "Single CMO (Common Market Organization) Regulation", which defines guidelines to protect the names of winemaking products by their place of origin: Designation of Origin - PDO - Protected designation of origin; Protected Geographical Indication - PGI - Protected Geographical Indication; Traditional Specialty Guaranteed - TSG - Traditional Specialty Guaranteed [18]. On the basis of this regulation, the name "Cognac" can only be used for strong drinks from wine distillate obtained from grapes collected within Cognac region of Charente and Charente Maritime, France [16].

The drinks similar to cognac are produced and sold under the name Armagnac in France, in Gascony province; it is called "brandy" in all other regions. Therefore, Ukraine (as well as other CIS countries) has no legal right to illegal use of the name "cognac" for its drinks and yet there has been no alternative name instead of the "cognacs of Ukraine". The name cognac was changed to Divin in Moldova and to Arbun in Armenia in recent years. 
The quality of winemaking products intended for domestic consumers in Ukraine is deliberately understated by the current normative documentation compared with the export products. Such practice is not used in any developed country where national interests are protected primarily against low-quality products and counterfeit goods, and the producer - against unfair competition from the outside. However, the legislation of these countries does not prohibit the sale of poor quality semi-finished wines and their distillates in other countries. It is confirmed by the fact that the warranted storage life of cognacs in Ukraine, according to DSTU (The State Standard of Ukraine) 4700: 2006, does not exceed 2 years. Warranted storage life of French cognacs is not limited [3,5,15].

Cognac standards in France are established and carefully monitored by the National Interprofessional Bureau of Cognacs - Bureau National Interprofessionnel du Cognac (BNIC) - an interprofessional institute established within the French legal system that brings together both cognac producers and related companies serving this branch of production: enologists, barrel makers, glassblowers, merchants and others. Besides, there is a strict state quality control - determination of cognacs and brandy authenticity using the most up-to-date multicomponent method: of Nuclear Magnetic Resonance (SNIF-NMR) and stable isotopes (IRMS) carried out by the Joint Laboratory Service -Service commun des laboratoires (SCL) attached to the National Service of the Ministry of Economy, Industry and Employment, the Ministry of Budget, Public Accounts, Services of Public Reforms of France [5].

The Cognac is not allowed for sale in France, if its maturation period in oak barrels is less than 2 years from distillation completion, that is, from April $01^{\text {st }}$ of the year following the harvest year. All processes from grapes to finished products are strictly controlled by BNIC service, and their violation is punishable by law. Unlike wine, Cognac's organoleptic properties are no longer evolving after bottling, so its age remains unchanged throughout the shelf life of the bottle [15].

The BNIC decision of August 23 $3^{\text {rd }}, 1983$, authorized by the French Government, implies the use of the age indication under the youngest distillate of grape origin matured in the barrel: "Eau de vie de Cognac" (eau-devi) and "Eau-de-vie des Charentes" in the assemblage that is a part of the drink. If there is a blend of cognac spirits of 3,5 and 6 years old, then the age of maturation of this mixture is considered to be 3 years (Table 1) [15].

1. Classification of French cognacs depending on the period of maturation in the barrel

\begin{tabular}{|l|l|l|l|l|l|l|}
\hline Index & \multicolumn{5}{|l|}{ French cognacs according to BNIC } \\
\hline $\begin{array}{l}\text { Maturation period, } \\
\text { years }\end{array}$ & $\geq 2$ & $\geq$ & $\geq 4$ & $\geq 5$ & $\geq 6$ & $\geq 10$ \\
\hline Classification & V.S. & Supérieur & V.S.O.P. & V.V.S.O.P. & Napoléon & X.O. \\
\hline
\end{tabular}

Consumers become aware about maturation of the drink in the barrel thanks to the special marking on the label:

- at least 2 years old - "V.S.", "Very Special", "3 Etoiles", "Sélection", "De Luxe", "Millésime";

- at least 3 years old - "Supérieur", "Cuvée Supérieure", "Qualité Supérieure";

- at least 4 years old - V.S.O.P. (Very Superior Old Pale), "Réserve", "Vieux", "Rare", "Royal";

- at least 5 years old - V.V.S.O.P. (Very Very Superior Old Pale), "Vieille Réserve", "Réserve Rare", "Réserve Royale";

- at least 6 years old - "Napoléon", "Très Vieille Réserve", "Très Vieux", "Héritage", "Très Rare", "Excellence", "Supréme";

- at least 10 years old - X.O. (Extra Old), "Hors d'àge", "Extra", "Ancestral", "Ancétre", "Or", "Gold", "Impérial" [15].

French law prohibits marking of cognacs the age of which exceeds 6 years old, as it is considered impossible to control their blend and quality. However, the marking of cognacs, the age of which is less than 10 years, and in some cases - more than 10 years against the documentary confirmation of this fact was allowed in 2016 [15].

Current DSTU 4700: 2006 "Cognacs of Ukraine" developed by 20 Ukrainian authors, slightly differs from the standard for cognacs of the former USSR (Table 2) [3]. Thus, its main provisions are borrowed from GOST (State Standard) 13741-91 of the USSR (which was re-approved from the previous GOSTs of the USSR, in 1968 at first, then in 1978) (Table 3).

The cognacs of Ukraine, depending on the terms of maturation, are divided into ordinary and vintage (see Table 2), which is incorrect from our prospective. Classification of French cognacs does not provide such a division [15]. 
2. Classification of the Ukrainian cognacs depending on the period of maturation in the barrel

\begin{tabular}{|l|l|l|l|l|l|l|l|l|}
\hline Index & \multicolumn{6}{l|}{ Ukrainian cognacs (DSTU 4700:2006) } \\
\hline $\begin{array}{l}\text { Maturation } \\
\text { period }\end{array}$ & \multicolumn{3}{l|}{ Ordinary } & \multicolumn{1}{l|}{ Vintage } \\
\hline Classification & $\geq 3$ & $\geq 4$ & $\geq 5$ & $\geq 6$ & $\geq 8$ & $\geq 10$ & $\geq 20$ & $6 \ldots 20+3$ \\
\hline & $3^{*}$ & $4^{*}$ & $5^{*}$ & MC & PQMC & OC & VOC & Collectible \\
\hline
\end{tabular}

Ordinary (from Latin - means without any features distinguishing among the others, common, customary) may have their own name and are made from spirits of grape origin, matured for $3-5$ years in barrels or in large tanks with oak staves. The Ukrainian cognacs «3 stars» are made from cognac spirits matured for at least 3 years; "4 stars" - from cognac spirits matured for at least 4 years; " 5 stars" - from cognac spirits matured for at least 5 years. Vintage cognacs of Ukraine are made from cognac spirits, matured only in oak barrels of middle age of at least 6 years and are divided into:

- MC - matured cognacs - made from spirits of at least 6 years old;

- PQMC - premium quality matured cognacs - made from spirits of at least 8 years old;

- OC - old cognacs - made from spirits of the average age > 10 years;

- VOC - very old cognacs - made from spirits of the average age $<20$ years old;

- collectible - specially selected vintage cognacs, additionally matured in a barrel for at least 3 years [3].

There have been changed some terms and formulations regarding the organoleptic characteristics of finished products in DSTU 4700: 2006. A category of VOC (very old cognacs) - at least 20 years old with negligible volumes of production was additionally introduced to the classification of vintage cognacs. At the same time, the authors do not provide instrumental methods for determining and controlling the maturation periods of cognac spirits and their authenticity, but they emphasize the sensory-subjective method of analysis of determination of their age in DSTU 4700: 2006, [1,3].

3. Classification of cognacs of the former USSR depending on the period of maturation in the barrel

\begin{tabular}{|c|c|c|c|c|c|c|c|}
\hline \multirow{2}{*}{ Index } & \multicolumn{6}{|l|}{ Cognacs (GOST 13741-91) } & Collectible \\
\cline { 2 - 8 } & \multicolumn{3}{|l|}{ Ordinary } & \multicolumn{2}{l|}{ Vintage } & $\geq 10$ years + 3 \\
\hline $\begin{array}{c}\text { Maturation } \\
\text { period }\end{array}$ & $\geq 3$ & $\geq 4$ & $\geq 5$ & $\geq 6$ & $\geq 8$ & 10 & Collectible \\
\hline Classification & $3^{*}$ & NS & $5^{*}$ & MC & PQM & OC & C \\
\hline
\end{tabular}

**) - $\mathrm{CH}$ - name-specific cognacs

Classification of Cognacs of the Customs Union is similar to the Ukrainian one under the years of maturation and also has the VOC category, but it does not contain any categories of ordinary and vintage cognacs (Table 4) [2].

4. Classification of cognacs of the Customs Union depending on the period of maturation in the barrel

\begin{tabular}{|l|l|l|l|l|l|l|l|l|l|}
\hline No. & Index & \multicolumn{6}{l|}{ Cognacs (Interstate Standard GOST 31732-2012 - AM, BY, KZ, KG, RU) } \\
\hline 1 & Maturation period & $\geq 3$ & $\geq 4$ & $\geq 5$ & $\geq 6$ & $\geq 8$ & $\geq 10$ & $\geq 20$ & $6 \ldots 20+3$ \\
\hline 2 & Classification & $3^{*}$ & $4^{*}$ & $5^{*}$ & MC & PQMC & OC & VOC & Collectible \\
\end{tabular}

Classification of the Ukrainian cognacs in comparison with the French one is imperfect and complex. It marks spirits of more than 20 years old (in French - up to 10 years old), that due the absence of the state quality (authenticity) control of the Ukrainian cognacs in Ukraine and according to the existing edition of the DSTU, makes it impossible to control the age of spirits and cognacs maturation by instrumental methods, that tempts the scammers and makes such a classification absurd. 
The definition of cognac spirits and cognacs age and the state control of their quality in Ukraine are entrusted to the Central Branch-Specific Taste Panel of Wine Industry - CBSTPWI (Order of the Ministry of Agrarian Policy of Ukraine dated January $22^{\text {nd }}, 2013$, No. 28) by the current legislation, and under the basic physical and chemical indexes of the DSTU - are entrusted to the State Enterprise "Ukrmetrteststandart" which is a profanation in our opinion. Because, firstly, the method of organoleptic analysis of CBSTPWI is subjective, and secondly, the specialists of laboratories of the State Enterprise "Ukrmetrteststandart", which develop methods and control the quality in wine making, are incompetent in the technology of wine, cognac and brandy. Therefore, it makes impossible to determine the age of cognac spirits and their authenticity in accurate manner [9].

The criterion for cognac spirits quality assessment, which is defined in the production, and are provided by the DSTU 4700: 2006 "Cognacs of Ukraine. Specifications", is the age of cognac spirits under the average duration of maturation in oak barrels. The average age of the Ukrainian cognacs is defined as the weightedaverage of the sum of ages of cognac spirits included in the blend [3].

The French classification differs by the fact that the age is determined by the indication of the age of the youngest distillate (eau-de-vie) of grape origin matured in the barrel that is included in the blend [15]. This is a fundamental difference in determination of the age of cognacs between two classifications (classical - French and Ukrainian).

Thus, according to the Section 5 General Technical Requirements and Specifications of the DSTU 4700: 2006 the quality of cognacs is characterized and determined not by instrumental methods but under organoleptic (subjective) indicators: transparency, color, flavor and taste. We read in the paragraph 5.1.1: Taste and flavor should be: "Traditional to the Ukrainian cognacs of a specific name, without foreign tones". We read in the paragraph 11. Methods of control "- there is no method for controlling the age of cognacs. We read in the paragraph 11.3: "Transparency, color, taste, and flavor of the cognacs of Ukraine are controlled organoleptically" [3].

The main indicators of quality of the cognac spirits imported into Ukraine (import is up to $80-90 \%$ ) are determined in accordance with the KD U 00011050-15.91.10 - 5:2009 "Technical requirements for imported cognac spirits" conditioned by their physical and chemical characteristics and can easily be falsified by adding the chemical components specified in the KD U and DSTU [3,4]. Among the organoleptic parameters monitored under $\mathrm{KD} U$, there are taste and a flavor (bouquet):

- for 1-3 years of maturation: flavor and bouquet - with light tones of maturation without foreign tones; taste is rather soft without foreign off-flavors;

- for 4-5 years of maturation: flavor and bouquet - traditional for matured cognac spirit with light floral tones without foreign tones; taste - with light tones of maturation, without foreign off-flavors;

- more than 5 years of maturation: a flavor - traditional for matured cognac spirit with light chocolatevanilla and floral tones without foreign tones; the taste is soft, harmonious with the tones of maturation, without foreign off-flavors.

The text of the DSTU does not explain how to understand the statement (or interpretation): "the taste and flavor should be traditional to the Ukrainian cognacs of a specific name", what do the terms "tone of maturation" or - "without foreign off-flavors" and the statement: "flavor - traditional for matured cognac spirit" mean, it is unclear which components and flavors they should consist of, and which valid normative documents contain the explanation of these statements, that is especially unclear for students and young cognac craftsmen.

The use of unclear, inaccurate interpretations and terms to determine the criteria for quality and age of the Ukrainian cognac spirits and cognacs in the KD U 00011050-15.91.10-5: 2009 and the DSTU 4700: 2006, according to their tasting assessment, is void because the organoleptic characteristics can not be use while appealing to the arbitration court to resolve disputes, since the sensory method of quality determining is based not on instrumental measurements of concentrations of chemical components of the drink, but on subjective tasting assessment. This is due to the variability of senses of different people as well as of the same person and depends on the state of organism, competence and experience of the experts [3-5]. At the same time, the above-mentioned normative documents do not take into account the control of cognac spirits authenticity, the age of the barrels and the degree of stave depletion $[5,13]$.

All of this can disorient both producers and those who control the quality of cognacs of Ukraine, therefore, the definition of criteria for cognac spirits quality and age assessment in KD $U$ and DSTU is imperfect, nonobjective and for these reasons puts brakes on the domestic winemaking and promotes an increase of imports of cognac spirits. Current classification of the Ukrainian cognacs requires harmonization of the above-mentioned normative documents with the requirements of the EU regulations. 
The organoleptic method of analysis in the European countries is used to control the quality of wines, cognacs and brandy as a secondary one, along with objective and scientifically based instrumental analytical methods that are officially recognized in the EU and have not yet been officially recognized in our country. However, the main methods for determining the authenticity of wines, cognacs and brandy in the EU countries are the methods of stable isotopes IRMS. According to the EU legislation, any country seeking to join the EU should have this instrumental method of food products control [5].

There are no instrumental methods of quality (authenticity) control and determination of cognacs and brandy distillates age in Ukraine, as well as a government agency that can carry out such control, therefore our research has been aimed at developing the criteria for cognac spirits maturity assessment based on concentrations of the main oak aromatic components passing to the spirit during its maturation in a barrel for 1-5 years.

Objective of the research is to develop criteria for cognac spirits maturity assessment by instrumental methods based on measurements of concentrations of the main oak aromatic components, which are extracted and accumulated in the wine distillate during its maturation in a barrel for 1-5 years.

Research methodology. Criteria for ordinary cognac spirits maturity assessment during their maturation in oak barrels is based on correlation between the age of cognac spirits matured in barrels (age index) and the accumulation of oak aromatic components - the main markers in them within this period: phenolic and aromatic oak wood substances (scopoletin, eugenol, vanillin, trans- and cis- $\beta$-methyl- $\gamma$-octalactone), which, according to the international oak wood classification for winemaking, are the main indicators of its quality.

Experimental maturation of cognac spirits in the new barrels with a capacity of $350 \mathrm{dm}^{3}$ made from domestic oak Quercus robur was carried out during 2003-2008 in the industrial environment of the Open Joint-Stock Company Agro-Industrial Firm "Tavria" (Nova Kakhovka).

Using the programs of statistical data processing (Excell), there was established an equation of the age index of cognac spirits from the concentrations of the studied components. Coefficients of the equation to determine the age index of cognac spirits are calculated for each studied component on the basis of reducing of their concentration in oak wood (depletion of wood) using statistical data processing programs (Excell). The age index values were calculated as the average amount of aging index values calculated for each component under the study.

The study of aromatic components in oak processing products was carried out as follows: $1 \mathrm{~g}$ of wood with an internal standard (amyl alcohol, $10 \mathrm{mg} / \mathrm{kg}$ ) had been extracted with $10 \mathrm{~cm}^{3}$ of diethyl ether for 2 hours. The other extract was evaporated to a volume of $0.05 \mathrm{~cm}^{3}$ and measured by chromatography method on a capillary column SE-30 and FFAP $(30 \mathrm{~m})$.

There were used the standards of the main markers of oak wood aromatic components of the following producers: Merck Schuchardt OhG, Aldrich Chem. Co, Fluka, Sigma.

Concentrations of oak aromatic components in cognac spirits were measured by the chromatographic method - direct injection of a sample using gas chromatograph "Crystal-2000M" with a flame-ionization detector, capillary column VITOKAP-AL-0.3 SP, phase - VITOWAX-F, length $50 \mathrm{~m}$, internal diameter 0,32 $\mathrm{mm}$. The concentration of scopoletin was measured using an ion chromatograph Dionex ICS-3000 [12, 13].

Findings of the study. An important part of determination of maturation age of cognacs is the analysis of physico-chemical components that give a specific flavor and taste to the drink and consist of the distillate components - a component of flavors passing from the grape wine material and forming during the process of distillation, and also - from the oak wood aromatic components that are extracted during the maturation period.

The aromatic components of cognac spirits determine the initial quality of young distillate by the compounds of ethyl, methyl and higher alcohols, aldehydes, esters, furfural, organic acids, aldehydes, acetals, etc. $[4,7]$. Concentrations of these components change during the period of maturation in the barrel, but not so noticeably compared with the oak wood components and influence on the process of forming the type of drink during maturation for 1-5 years.

The main aspect of formation of the cognac spirits quality and cognac type during maturation in the barrel is an increase of concentration of oak wood components in spirit due to the processes of hydrolysis, ethanolysis and extraction $[7,13]$. In view of this, in order to assess the quality of distillates and cognacs, it is expedient to select specific markers - the components that give a specific elite flavor, bouquet and taste to a drink, form maturation age of the spirits and minimize their artificial adding to the drink $[6,13]$.

From the second half of the twentieth century the intensification of cognacs and brandy production contributed to the search of effective methods of quality assessment of the drink and determination of its maturation age by means of instrumental analysis methods $[5,8]$. 
Most scientific studies aimed at determination of authenticity and age of cognac spirits are devoted to the products of hydrolysis of lignin form aromatic aldehydes formation: lilac, synaptic, coniferyl aldehydes and vanillin $[9,11,12]$. However, these components do not fully reflect the range of oak aromatic components passing to cognac spirit during maturation, and also, except for vanillin, are not included to the international classification of oak wood for winemaking $[7,13]$. Basing on the international classification of oak wood for winemaking and on ideology of the leading scientists in the research and use of oak wood for cognacs and brandy production, we chose specific markers - components that give a traditional (cognac) flavor, bouquet and taste that is formed during maturation (vanillin, eugenol, trans- and cis- $\beta$-methyl- $\gamma$-octalactone, phenol substances, scopoletin) and other aromatic aldehydes as the criteria for determination of the age index of spirit. The use of scopoletin as a marker, is due to the fact that it has a resinous (cedar) shade in the bouquet and taste of cognac spirit and is involved in the process of "aging" of cognacs [6,13]. Determination of concentrations of the above aromatic components during the analysis of spirits characterizes the "age index" of cognacs and brandy [8]. The study of concentration of these components in the Ukrainian cognacs to determine their age was not conducted.

In order to develop criteria for optimization of the process of oak aromatic complex forming in cognac spirits during maturation in oak barrels or in contact with oak staves in large tanks, the age index of cognac spirits was determined on the production base of the Open Joint-Stock Company Agro-Industrial Firm "Tavria" (Nova Kakhovka, Kherson region). We determined the concentration of the main oak wood aromatic components - vanillin, eugenol, trans- and cis- $\beta$-methyl- $\gamma$-octalactone, phenolic substances, lilac and coniferial aldehydes and scopoletin in wine distillates of Rkatsiteli grape.

There was studied chemical composition of cognac spirits, aged in oak barrels for 1-5 years - 5 samples of blend of each age (according to the middle age). There were determined averaged data of concentrations of oak components according to the individual blends (Table 5). On their basis, the diagrams of dependence of components concentration on the duration of spirit maturation (fig.) were made.

Among the studied components, there have been observed noticeable changes in concentrations for trans- and cis- $\beta$-methyl- $\gamma$-octalactone and lilac aldehyde, which are the best markers to determine the age of cognac spirit, as it has been defined in subsequent calculations. 


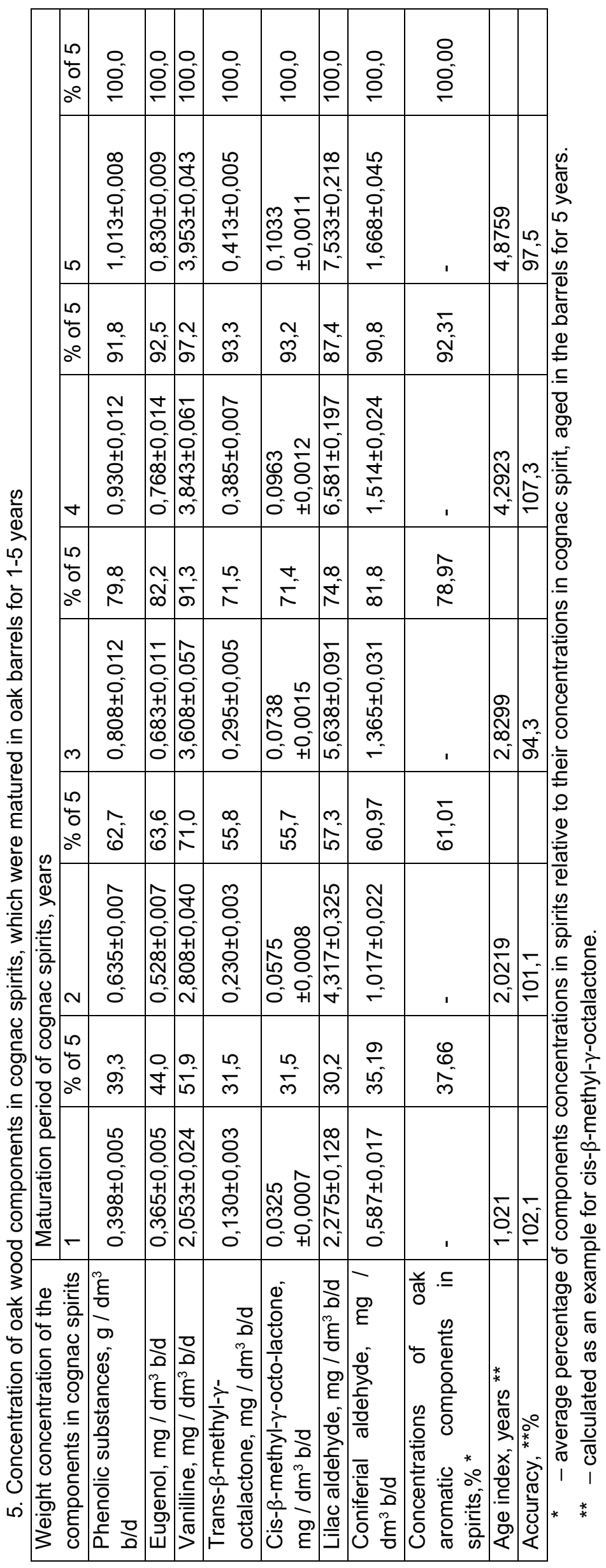




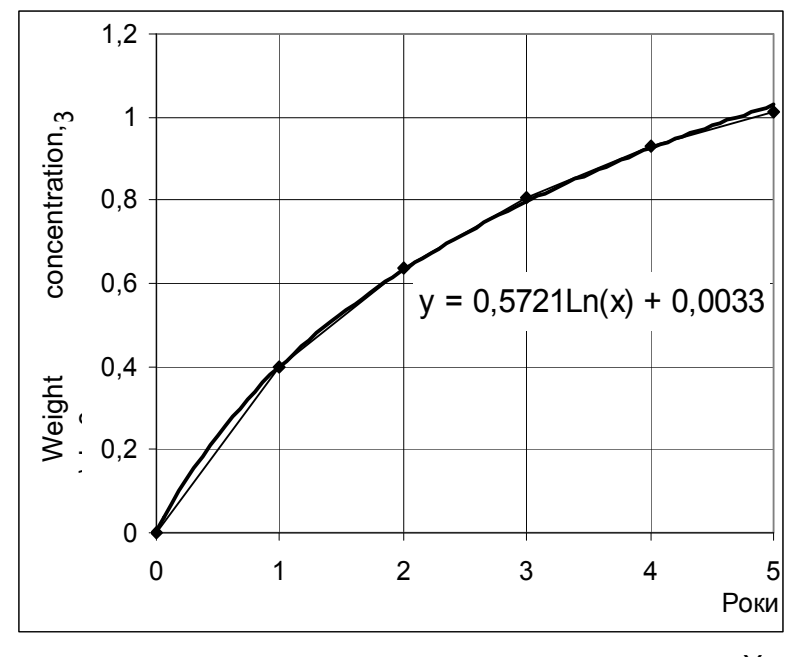

a

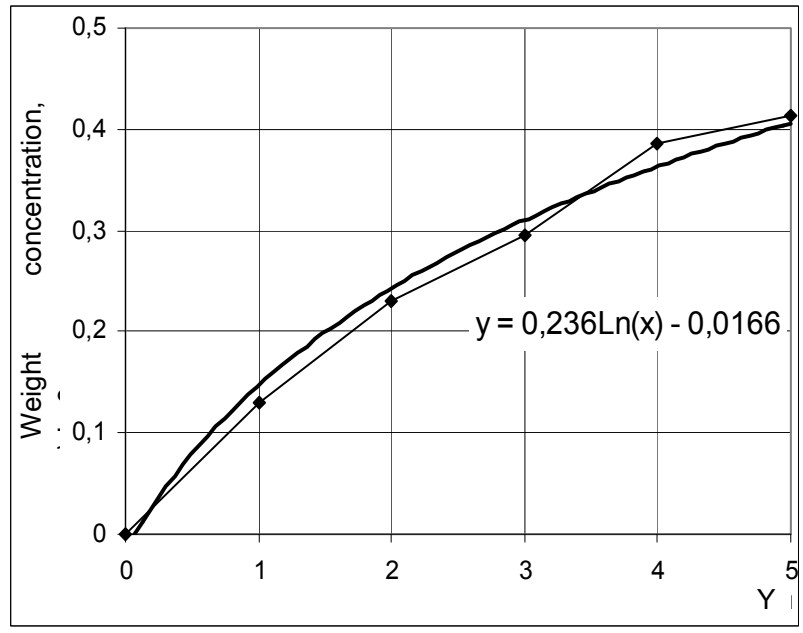

C

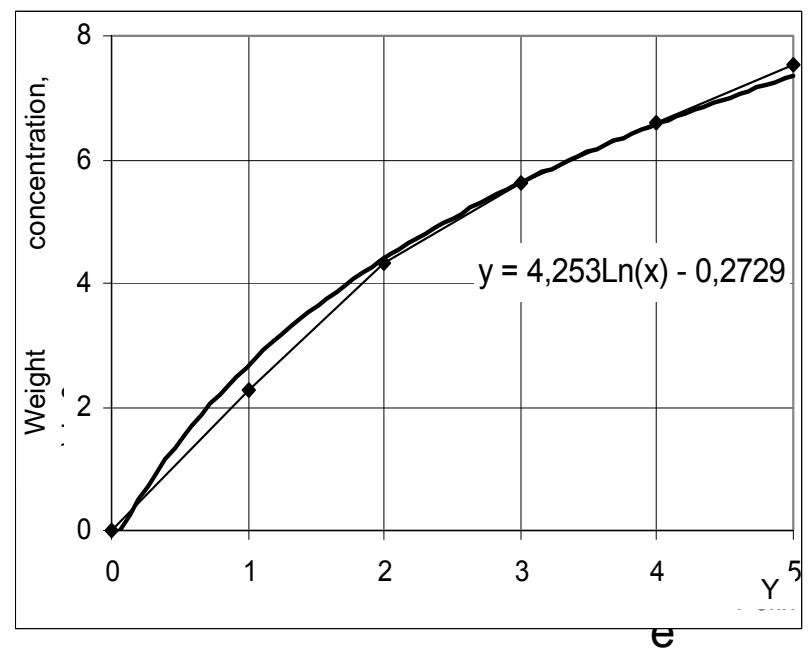

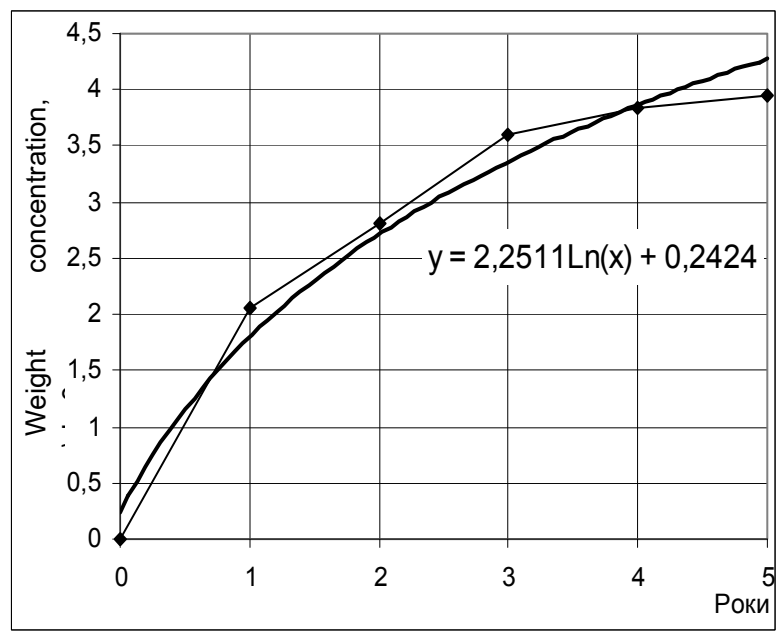

b

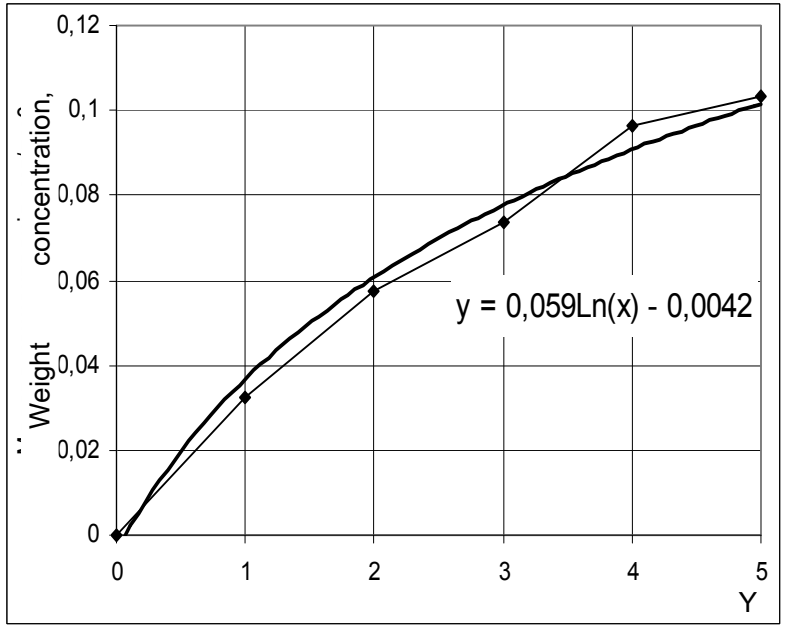

d

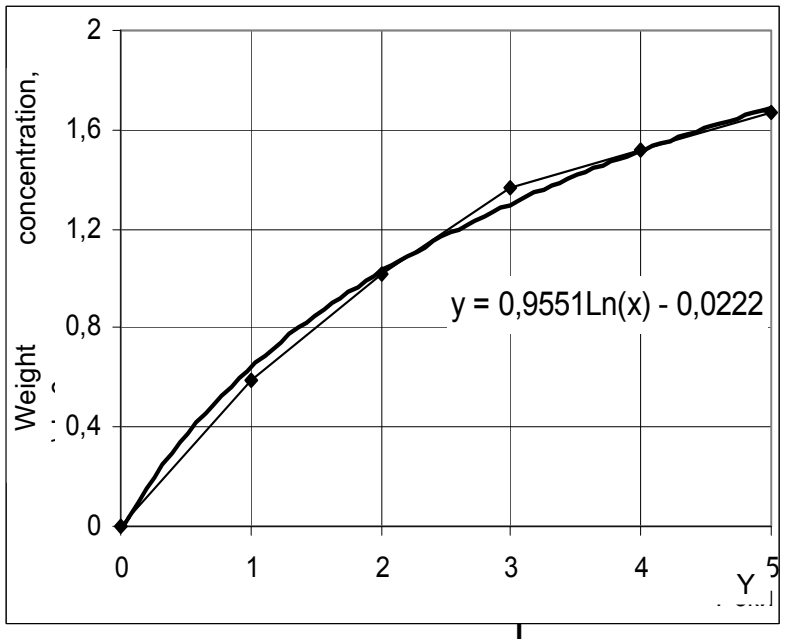

Dependence of concentrations of oak aromatic components in cognac spirits on the duration of its maturation in the barrel (actual values and their averaging): $a$ - phenol substances; $b$ - vanillin; $c$ - trans- $\beta$ methyl- $\gamma$-octalactone; $d$ - cis- $\beta$-methyl- $\gamma$-octalactone; $e$ - lilac aldehyde; $f$ - conigeral aldehyde

Lets conditionally assume that the rate of extraction of oak components is proportional to their depletion in the wood. Then the change of concentrations in the wood will formally correspond to the exponential equation:

$C(t)=C * \exp ^{(-k t)}$, 
where $\mathrm{C}=\mathrm{C}(0)$ - the concentration of oak wood components at the beginning of the extraction process (i.e., the natural reserve of components in the wood).

Consequently, the concentration of components in cognac spirit $A(t)$ will be:

$A(t)=C-C^{*} \exp ^{(-k t)}$

Having assumed that $A(t)=C-C^{*} \exp (-k t)$, and having applied the sum of squares minimization method, we obtained the values of $\mathrm{C} 1, \mathrm{C} 2$ and $\mathrm{k}$ coefficients (Table 6) from the experimental data.

\section{Results of the sum of squares minimization}

\begin{tabular}{|c|c|c|c|c|}
\hline \multirow{2}{*}{$\begin{array}{l}\text { Weight concentration of the } \\
\text { components in cognac spirits }\end{array}$} & \multicolumn{4}{|l|}{ Indexes } \\
\hline & $\mathrm{C}_{1}\left(\mathrm{C}_{0}\right)$ & $\mathrm{C}_{2}$ & $\mathrm{C}_{1}-\mathrm{C}_{2}$ & $\mathrm{~K}$ \\
\hline Phenolic substances, $\mathrm{g} / \mathrm{dm}^{3} \mathrm{~b} / \mathrm{d}$ & 1,2 & 1,117 & 0,083 & 0,3693 \\
\hline Eugenol, $\mathrm{mg} / \mathrm{dm}^{3} \mathrm{~b} / \mathrm{d}$ & 0,94 & 0,921 & 0,019 & 0,4234 \\
\hline Vanilline, $\mathrm{mg} / \mathrm{dm}^{3} \mathrm{~b} / \mathrm{d}$ & 4,095 & 4,943 & $-0,848$ & 0,6873 \\
\hline Trans- $\beta$-methyl- $\gamma$-octalactone, $\mathrm{mg} / \mathrm{dm}^{3} \mathrm{~b} / \mathrm{d}$ & 0,61 & 0,6066 & 0,0034 & 0,2318 \\
\hline Cis- $\beta$-methyl- $\gamma$-octo-lactone, $\mathrm{mg} / \mathrm{dm}^{3} \mathrm{~b} / \mathrm{d}$ & 0,15 & 0,1498 & 0,0002 & 0,2394 \\
\hline Scopoletin, $\mathrm{mg} / \mathrm{dm}^{3} \mathrm{~b} / \mathrm{d}$ & 178,0 & 175,838 & 2,162 & 0,7083 \\
\hline Lilac aldehyde, $\mathrm{mg} / \mathrm{dm}^{3} \mathrm{~b} / \mathrm{d}$ & 10,1 & 9,529 & 0,571 & 0,2716 \\
\hline Coniferial aldehyde, $\mathrm{mg} / \mathrm{dm}^{3} \mathrm{~b} / \mathrm{d}$ & 1,95 & 1,9457 & 0,0043 & 0,3873 \\
\hline Sinapic aldehyde, мг/дм³ б.с. & 6,7 & 5,952 & 0,748 & 0,1758 \\
\hline
\end{tabular}

The similarity of $C 1$ and $C 2$ values (see Table 6 ) is the confirmation of the assumption that $A(t)=C-$ $C^{*} \exp ^{(-k t)}$. Similar data have been obtained for eugenol, both isomers of $\beta$-methyl- $\gamma$-octalactone, coniferial aldehyde and scopoletin.

Proceeding from the above, the age index of cognac spirit or cognac can be calculated by the formula:

$\mathrm{t}=-(1 / \mathrm{k}) \ln \left(1-\mathrm{C} / \mathrm{C}_{0}\right)$

where: $t$ - index of age;

$\mathrm{k}$ - calculated coefficient of speed of the process of cognac spirits typicalness forming for: phenolic substances - 0,3693 , eugenol - 0,4234 , vanillin - 0,6873 , trans- $\beta$-methyl- $\gamma$-octalactone $-0,2318$, cis- $\beta$ methyl- $\gamma$-octalactone $-0,2394$, lilac aldehyde $-0,2716$, coniferial aldehyde $-0,3873 ; C$ is a concentration of the component in matured cognac spirit, $\mathrm{mg} / \mathrm{dm}^{3} ; \mathrm{C}_{0}$ is an average initial concentration of the component in the wood: phenolic substances - 1,2, eugenol - 0,94 , vanillin - 4,095, trans- $\beta$-methyl- $\gamma$ octalactone - 0,61, cis- $\beta$-methyl- $\gamma$-octalactone - 0.15 , lilac aldehyde - 10.1, coniferial aldehyde - 1.95 .

As a result, making calculations under developed formula, the age index of cognac spirit or cognac can be calculated up to the accuracy of $98.68 \%$ with a relative standard deviation of $10 \%$ (Table 5).

If we take the concentration of oak aromatic components in spirit during maturation in a new barrel for a period of 5 years - as $100 \%$, then their concentration increases by $38 \%$ for the first year of maturation, by 61 - for the 2nd year, by 79 - for the 3-rd, by $92 \%$ - for the 4th, and therefore the "index of age" over the years will be: 1,021 - after the 1st year of maturation; 2.0219 - after the $2^{\text {nd }}$ year of maturation; 2,8299 - after the 3rd year of maturation; 4.2293 - after the 4th year of maturation and 4.8759 - after the 5th year of maturation.

In a point of fact, the age index is an empirically found indicator that characterizes the duration of cognac maturation in new oak barrels. It can be used not only to determine the age of spirits, but also as an objective criterion of quality or extractual intensity of spirits or cognacs when comparing the products of different manufacturers. A similar criterion can be the content of other volatile components of oak and distillate, which change and accumulate in the process of spirits maturation.

Therefore, the age index is a conditional indicator, the value of which varies somewhat due to uneven correlation between the individual components of oak wood and the age of cognac spirits matured in the barrels. The reason for this is the difference in chemical composition of oak wood, which depends on its botanical species, age and place of growth, the method of staves drying- afterripening, the degree of depletion of the wood of oak staves by the distillate, etc.

However, such a correlation occurs when these parameters are the same for a particular enterprise, taking into account the production of the same type of cognac products. Therefore, in order to obtain the general norms of the age index values for their inclusion to the standardized indicators of cognac quality assessment, it is necessary to continue similar studies of authentic cognac spirits of different manufacturers. 


\section{Conclusions}

There was made a comparative analysis of cognac classifications according to their maturation age in the barrel, which is stipulated in BNIC regulations of France, DSTU and GOSTs of Ukraine.

Classification of the Ukrainian cognacs in comparison with the French one is imperfect and more complicated. It marks spirits of over 20 years old (in French classification - up to 10 years old), and due to absence of state control over the authenticity of winemaking products in Ukraine and according to the current edition of the DSTU, it makes impossible to control the maturation period of spirits and cognacs by instrumental methods that tempts fraudsters.

The current classification of cognacs in Ukraine is adapted to the Customs Union market and does not meet the requirements of the EU legislation, which prevents domestic enterprises from entering the European brandy market. The established minimum age for cognac spirits in Ukraine is 3 years, compared with 2 years in France, prompting manufacturers to increase the volumes of cognac spirits import and leading to destruction of winegrowing and winemaking industry. However, the country has rather significant competitive advantages over the EU producers in some segments of winemaking industry.

There was offered the criterion of ordinary cognac spirits maturity assessment on the basis of measurements of concentrations of the main oak aromatic components accumulated in spirit during its maturation in the barrels for 1-5 years. To calculate the age index (t), there has been established a dependence: $t=-(1 / k) \ln \left(1-C / C_{0}\right)$, where: $k$ - coefficient of speed of the process of cognac spirits typicalness forming; $\mathrm{C}$ - concentration of the component in the matured cognac spirits, $\mathrm{mg} / \mathrm{dm}^{3} ; \mathrm{C}_{0}$ average output concentration of the component in wood, $\mathrm{mg} / \mathrm{dm}^{3}$.

\section{Bibliography}

1. GOST 13741-91 Cognacs. General specifications / N.H. Sarishvili, V.S. Litvak, L.N. Benevolenskaya, I.V. Starodubtseva - Moscow: Gosstandart USSR, 1991. - 10 p.

2. GOST 31732-2012 Cognac. General specifications / Interstate standards. - Moscow: Standardinform, 2013. - $7 \mathrm{p}$.

3. DSTU 4700: 2006 Cognacs of Ukraine. Specifications / Alterations: 11-2007, 1-5-2008 / A.Aidzba, M.Agafonov, R. Bilan, O. Vasylyk, V.Herzhykova, V.Honcharenko, T.Horbova, R.Huliiev, O.Dernova, V.Zahoruiko, N.Kravchenko, T.Nacheva, Y.Ogai, Y.Olkhovyi, O.Paliekha, M.Sachavo, L.Strelnytskyi, V.Strmiadin, N.Tolstenko, V.Furkevych, A.Yalanetskyi / Derzhspozhyvstandard Ukraine, 2007. - 12 p.

4. KD U 00011050-15.91.10-5: 2009. Technical requirements for import cognac spirits / Chenusha S.A., Herasymchuk L.I., Nacheva T.O. - Kyiv: Ministry of Agrarian Policy of Ukraine, 2009. - 5 p.

5. Lukanin A.S., The Ukrainian wine with an import off-flavor, / / Drinks. Technologies and innovations. - Kyiv: PE Polygraphinter, 2014. - No. 3. - P. 25-28.

6. Ohanesiants L.A. / Oak and winemaking. - Moscow: Food Industry, 1998. - 256 p.

7. Skurykhin S.M. Cognac and brandy chemistry - Moscow .: DeLi Print, 2005. - 296 p.

8. Determination of cognacs (brandy) age I Panosian A.H., Mamikonian G.V., Torosian M.A., Abramian A. and others. // Medicine. - 2002. - No. 4. - P. 59-62.

9. Kishchenko V., Falsification of cognacs by gas chromatic-mass spectrometry method / V. Kishchenko, I. Levchuk, V. Semenovych // Standardization, certification, quality .- Kyiv: SE "Ukrmetrteststandart", 2011.-No.5. - P. 38-40.

10. V.M. Zhyrov. Identification of cognac spirits and cognacs authenticity according to the composition of volatile components. V.M. Zhyrov, M.V. Babaieva // Technologies of the XXI century in light industry. 2012. - No. 6, P. 1 - 9.

11. Oseledtseva I.V. Practical implementation of modern methods for cognac products authenticity determination / I.V. Oseledtseva, T.I.Huhuchkina, E.M. Sobolev // News of the Higher Educational Institutions. Food technology. - No. 2-3. - P. 104-106.

12. Cherkashyna Y.A. Chromato-mass-spectral estimation of the component composition of cognac products / Y.A. Cherkashyna, N.N. Sarvarova, M.I. Evgeniev // Kazan Technological University Reporter. Food Industry - 2009. - No 4. - P. 1-16.

13. Vivas N. Manuel de tonnellerie à l'usage des utilisateurs de futaille / Vivas N. // Editions Féret. Bordeaux: 2002. $-207 \mathrm{p}$.

14. Jean Gabilly, Élie Cariou et alii, Guides géologiques régionaux, Poitou, Vendée, Charentes, Paris, Masson, 1997, 223 p. (ISBN 2-225-82973-X) 
15. Specifications for the registered designation of origin "Cognac"or "Eau-de-vie de Cognac" or "Eaude-vie des Charentes". - published in BO AGRI on 15.01.2015.- I.N.A.O. 2015. - 20 p.

16. Council Regulation (EC) No. 1234/2007 of 22 October 2007 establishing a common organisation of agricultural markets and on specific provisions for certain agricultural products (Single CMO Regulation)./Official Journal of the European Union. - 16.11.2007. - 299 L.

17. Regulation (EC) No 110/2008 of the European parliament and of the council of 15 January 2008 on the definition, description, presentation, labelling and the protection of geographical indications of spirit drinks and repealing Council Regulation (EEC) No 1576/89. - Official Journal of the European Union 13.2.2008. - L 39 .

18.http://ec.europa.eu/agricuiture/quality/ - EU agricultural product quality policy//EU qulity/ schemes for agricultural products 